ISSN (print): 1698-6180. ISSN (online): 1886-7995

www.ucm.es/info/estratig/journal.htm

Journal of Iberian Geology 37 (2) 2011: 177-193

doi: 10.5209/rev_JIGE.2011.v37.n2.7

\title{
The recorded evidence of AD 1755 Atlantic tsunami on the Gibraltar coast
}

\author{
Las evidencias registradas del tsunami atlántico de 1755 en la costa de Gibraltar
}

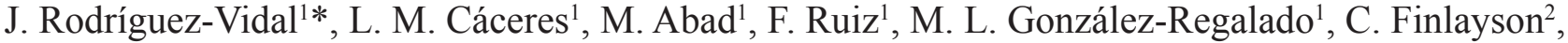 \\ G. Finlayson², D. Fa², J. M. Rodríguez-Llanes³, G. Bailey ${ }^{4}$ \\ ${ }^{1}$ Departamento de Geodinámica y Paleontología, Campus del Carmen, Avda. Tres de Marzo s/n, Universidad de \\ Huelva, 21071-Huelva, Spain \\ ${ }^{2}$ The Gibraltar Museum, 18-20 Bomb House Lane, Gibraltar, UK \\ ${ }^{3}$ Centre for Research on the Epidemiology of Disasters, Institute of Health and Society, Université catholique de \\ Louvain, Clos Chapelle-aux-Champs, 1200-Brussels, Belgium. \\ ${ }^{4}$ Department of Archaeology, University of York, The King's Manor, York Y01 7EP, UK \\ *corresponding author: jrvidal@uhu.es \\ Phone: +00 34 959219862; Fax: +00 34959219440
}

Received: 30/04/11 / Accepted: 19/10/11

\begin{abstract}
Evidence of the AD 1755 tsunami consisting of the same type of accretions produced by the re-deposition of earlier sediments, has been recorded at three different height along the coast of Gibraltar: Along a shallow sandy shore, the tsunami wave reached a run-up of 2-3 m, whereas along steep, cliff-lined shores (Rosia Bay) it surpassed $5 \mathrm{~m}$. An overwash deposit was also identified at the bottom of a lagoon (The Inundation), at $0.5 \mathrm{~m}$ b.s.1., on the isthmus that joins the Rock with the mainland. Southern submerged platforms (Vladi's Reef) were also affected by the erosional backwash to a depth of $22 \mathrm{~m}$. The tsunamigenic sediments exhibit a bimodal granulometry, mainly composed of sands with a coarser fraction composed of marine faunal shells remains, together with larger clasts derived from the rocky substrate. All remobilized sediments were dated by historical methods and radiocarbon dating.
\end{abstract}

Keywords: Lisbon earthquake, AD 1755 tsunami, run-up, sedimentary record, radiocarbon dating, Gibraltar

\section{Resumen}

Se han registrado evidencias del tsunami de 1755 localizadas a tres alturas diferentes a lo largo de la costa de Gibraltar, todas ellas como resultado del mismo tipo de acreción producida por el re-depósito de sedimentos previos. A lo largo de las costas bajas y arenosas estudiadas, la ola del tsunami alcanzó una altura de 2 a $3 \mathrm{~m}$, mientras que en litorales acantilados y con fuertes pendientes 
sobrepasó los $5 \mathrm{~m}$. Se ha identificado un posible registro sedimentario en el fondo de una laguna costera (Inundation), a $0.5 \mathrm{~m} \mathrm{b.n.m}$., en el istmo que une la Roca con el continente. Por otro lado, las plataformas sumergidas, como la meridional de Vladi's Reef, sufrieron erosión por la retirada de las olas a una profundidad de hasta $22 \mathrm{~m}$. Los sedimentos tsunamigénicos poseen una granulometría bimodal, compuesta principalmente de arenas con una fracción más gruesa de restos de conchas marinas, junto con cantos mayores de rocas provenientes del sustrato. Todos los sedimentos removilizados por el tsunami han sido datados por métodos históricos y de radiocarbono.

Palabras clave: Terremoto de Lisboa, tsunami del 1755, altura del tsunami, registro sedimentario, datación por radiocarbono, Gibraltar

\section{Introduction}

Although the Atlantic coasts of Europe are at considerably less seismic risk than those of the Pacific or Indian Oceans, there is historical and geological evidence of seismogenic tsunamis that affected Western Europe and Northwestern Africa. These earthquakes and tsunamis were generated in the SW Iberian Transpressive (SWIT) domain (Fig. 1A), which is interpreted as a complex plate boundary (JiménezMunt and Negredo, 2003; Zitellini et al., 2004). The most active zone is located SW off Portugal (Cape St. Vincent), which is apparently the source of the last and most destructive tsunami - known as the " 1755 Lisbon Earthquake", $M_{w}$ $8.5 \pm 0.3$ (Solares and Arroyo, 2004).

There have been several studies on the location and the rupture mechanism but it is still a matter of debate (Fonseca, 2005). For these studies, some authors have used macroseismic data (Martínez Solares et al., 1979; Levret, 1991) and data regarding the amplitude of the tsunami (Abe, 1979), were compared to the well-studied February 1969 event (Johnston, 1996). As a result, for some years the seismic source was assumed to be located south of the Gorringe Bank, at the Horseshoe abyssal plain (Fig. 1A). Other studies based on the analysis of the historical data on the wave height detected along the Iberian and Moroccan coasts, determine a source area nearer SW of the Portuguese continental margin (Baptista et al., 1998b). More recently, diverse studies of multi-channel seismic reflection surveys were performed in south Iberia, resulting in new interpretations and possible sites SW of cape St. Vincent, in the region known as Marquês de Pombal Thrust fault (Zitellini et al., 1999, 2001). The rupture in this region, along with the rupture that could occur simultaneously at the Guadalquivir Bank, located further to the SE, could have provided enough energy for an event like the one in 1755 (Baptista et al., 2003). Regardless of previous work, within the last few years some novel interpretations have appeared which suggest a model with subduction of the Atlantic part of the African plate under the Arc of Gibraltar (Gutscher, 2004; Gutscher et al., 2006), which could also explain the generation of energetic earthquakes that could originate tsunamis such as the one in 1755 .
The historical evidence and sediments that this tsunami has left on the Portuguese and Spanish coasts can be employed to test the validity of such indicators in the localisation of its epicentral zone. The greater or lesser precision in the search will depend on the quality and reliability of the markers used and on the suitability of the coastal outcrops examined and/or the trenching/coring made.

Usually, tsunamis move landward generating deposits as a result of drag and erosion of deeper areas or coastal barriers nearer the open sea (Dawson and Stewart, 2007). So within the last few years numerous researchers have analyzed the geological record of past high-energy events (tsunamis, storms) around the world, including lithostratigraphical, sedimentological, faunal, geochemical, and radiocarbon and luminiscence dating for this purpose (Clague et al., 2000; Goff and McFadgen, 2002; Radtke et al., 2003; Smith et al., 2004; Andrade et al., 2006; Ruiz et al., 2005, 2008; Pozo et al., 2010; Cunha et al., 2010).

In this study we aim to provide an initial contribution to the historical and geological evidence of the 1755 tsunami and of its effect upon various coastlines (sandy low-lying, rocky and cliff), as well as submerged zones around the Rock of Gibraltar (Fig. 1B).

\section{Regional effects and record of the AD 1755 tsunami}

The Lisbon earthquake and its subsequent tsunami were the greatest natural catastrophe that affected Europe in recent history and its effects left a mark in the collective memory of the inhabitants of the Iberian coast. The greatest impact occurred in Lisbon city, with almost 900 direct victims. Many other Portuguese coastal populations were also affected, some of which were destroyed, although the number of victims was lower than in the capital city. The effects of the tsunami are also described in areas of Spain and the African Atlantic coast, as well as in Cornwall, and even the agitation in closed waters of faraway places like Scotland (Chambers, 1757; Bewick, 1757; Borlase, 1755; Mendonça, 1758). Finally, there are also evidences of the tsunami impact on the other side of the Atlantic, in the Caribbean islands. 


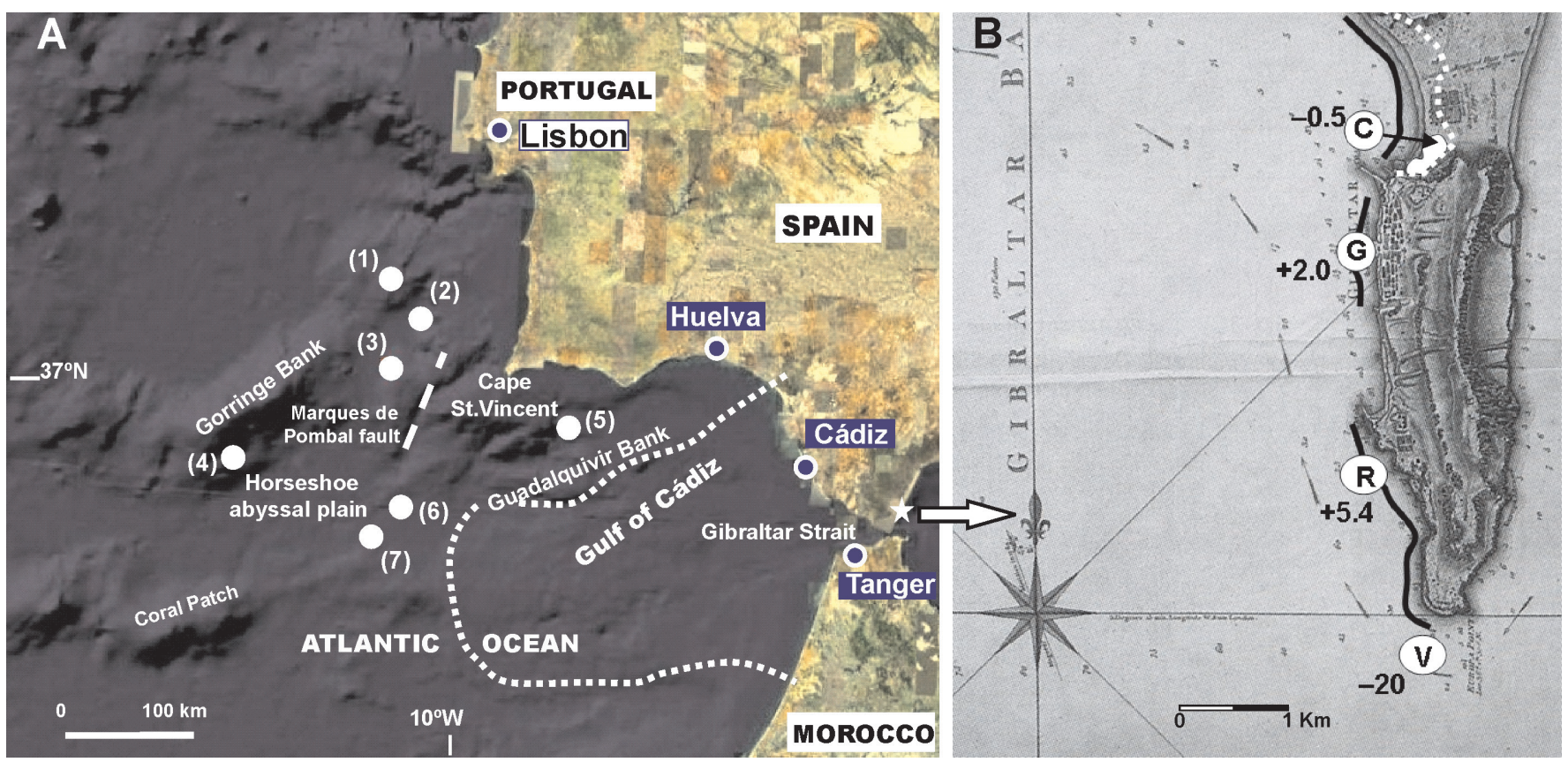

Fig. 1.- Geographical setting of Cádiz Gulf area and Gibraltar Rock. A. Geographical location of the St. Vincent-Cádiz tsunamigenic area (SW Iberian Transpressive (SWIT) domain). White dots are epicentral regions proposed by several authors for the AD 1755 earthquake: (1) Reid (1914), (2) Terrinha et al. (2003), (3) Zitellini et al. (1999), (4) Machado (1966), (5) Baptista et al. (2003), (6) Moreira (1989), (7) Barkan et al. (2009). White dotted line shows an accretionary tectonic wedge probable source of this earthquake (Gustcher, 2004). B. Plan of the Rock and town of Gibraltar (1769-1775), engraved by W. Faden 1781. C, the Inundation lagoon. G, Gibraltar Harbour. R, Rosia Bay. V, Vladi's Reef. White dotted line is the limit of the area inundated by the tsunami and number is its elevation into the study site.

Fig. 1.- Encuadre geográfico del área del Golfo de Cádiz y el Peñón de Gibraltar. A. Localización geográfica del área tsunamigénica San Vicente-Cádiz (SW Iberian Transpressive (SWIT)). Los círculos blancos son zonas de epicentros propuestos por varios autores para el terremoto de 1755: (1) Reid (1914), (2) Terrinha et al. (2003), (3) Zitellini et al. (1999), (4) Machado (1966), (5) Baptista et al. (2003), (6) Moreira (1989), (7) Barkan et al. (2009). La línea discontinua blanca muestra un cuña tectónica de acreción, probable fuente de este terremoto (Gustcher, 2004). B. Mapa del Peñón y la ciudad de Gibraltar (1769-1775), grabado de W. Faden 1781. C, la laguna The Inundation. G, Puerto de Gibraltar. R, Bahía de Rosia. V, Arrecife de Vladi. La línea discontinua blanca marca el límite del área inundada por el tsunami y los números indican su elevación en los lugares estudiados.

\subsection{African coast}

Recently, Kaabouben et al. (2009) and Blanc (2009) have published two separate studies in which they compile and revise the historical references of the effects of diverse tsunamis, especially from the one in 1755, in several cities of NW Africa. According to these historical sources, the greatest impact occurred in the city of Tanger, where the waves swept over the fortifications, which suggests $15 \mathrm{~m}$ of run-up, and which penetrated around $2 \mathrm{~km}$ inland; the tsunami waves repeated eight to nine times with sea level rising and falling some 18 times over 8 hours. The effects were lower in other cities like Safi and Salé, where the flooding spread inland $1,200 \mathrm{~m}$ and 2,000 $\mathrm{m}$ respectively. The height of the tsunami waves reached about $2.5 \mathrm{~m}$ in Ceuta, and the historical sources in El Jadida suggest a run-up of 22.5 $\mathrm{m}$, although this fact is unreliable. The flooding of the successive waves and their subsequent withdrawal resulted in the drag and deposition of sediments, ships and a large number of fish on to land (Fowke, 1756), and it also caused a strong erosion in some areas, such as in El Jadida, where rocks were exposed.

However, Blanc (2009) revises and carefully discusses the different information sources concluding that the tsunami was not greater in Africa than in Cádiz $(2.5 \mathrm{~m}$ amplitude - i.e. height at shoreline minus expected tide level - after Godin, 1755), decreasing to between $2 \mathrm{~m}$ and $1.5 \mathrm{~m}$ further south at the coasts of Morocco. Thus, the run-up is reduced and a $2.5 \mathrm{~m}$ amplitude, similar to that in other points of the Moroccan coast, is estimated.

Despite the important impact of the tsunami in the African coast, there has been no knowledge about clear sedimentological evidence until now (Kaabouben, 2009). Only Mhammdi et al. (2008) investigate large boulders (4-100 tons) along the Rabat coast. These boulders may be single, imbricate sets or forming clusters and ridges. Despite the absence of absolute dating, the authors interpret their current locations and arrangement to the 1755 tsunami. 


\subsection{American coast}

There are several references to the impact of the 1755 Lisbon tsunami on the Atlantic coasts of America, mostly in the Caribbean islands. Impacts are described in Antigua and Barbados, where the waves flooded harbours and some houses, with a run-up of $3.7 \mathrm{~m}$ and 1.5-0.8 $\mathrm{m}$, respectively. The run-up was also estimated for other Caribbean and Antillean islands: Dominica with $3.7 \mathrm{~m}$, Saba with $6.4 \mathrm{~m}$ and St. Martin with $4.5 \mathrm{~m}$ (Lander et al., 2002). There are references of the effect of the tsunami in the islands of Hispaniola and Cuba as well (O'Loughlin and Lander, 2003), but it was not recorded along the U.S. Atlantic seaboard (Barkan et al., 2009). However, Shepherd (2001) performed a systematic review of the West Indies historic data, concerning the 1755 event, reducing the average amplitude in the area to $2-3 \mathrm{~m}$, and found that no damage or casualties were reported.

Sedimentary evidences of the tsunami were suggested for the island of Anegada (140 km ENE of Puerto Rico) by Atwater et al. (2010). These researchers found several evidences for overwash in the island: dozens of breaches on the north side of the island; a clastic-sediment sheet that consists mainly of sand and shelly sand that extends at least $1.5 \mathrm{~km}$ inland. This overwash occurred beetwen AD 1650-1800, so it could have resulted from the transatlantic Lisbon tsunami of 1755.

\subsection{Portuguese coast}

The maximum impact of the earthquake and the subsequent tsunami occurred along the coast of Portugal. Baptista and Miranda (2009) made a compilation of the historical references of this and other tsunamis that affected this coast. Chronicles of that time described waves of 10-15 $\mathrm{m}$ at Cape St. Vincent and along the Gulf of Cádiz. In Lisbon, where the earthquake damage was greatest, the number of casualties, due exclusively to the tsunami, was estimated to be close to 900 and the run-in, in Lisbon downtown, is thought to be $250 \mathrm{~m}$, with a wave height of $5 \mathrm{~m}$ (Baptista et al., 1998a). In Setubal, south of Lisbon, the sea destroyed the city walls and penetrated for up to a quarter of a mile. In Porto (Oporto), the second city of Portugal, the tsunami caused severe rise and fall of the Douro/Duero river level at its mouth, damaging some ships in the harbour. In the Algarve, south of Portugal, the sea level rose flooding fields for more than a league inland, and its retreat caused extensive damage, demolishing many of the strongholds that were located along the coast, such as the one at Lagõa. Eastward, fishermen's huts were destroyed, from Monte Gordo to Tavira, along with the barrier islands in the coast up to Quarteira. West- ward, cities such as Lagos and Albufeira, suffered considerable damage in much of their urban centers. Similar events are described in other points of the Portuguese geography, such as the Atlantic islands of Madeira and Porto Santo, with a wave height of $4 \mathrm{~m}$ in the former (Baptista et al., 1998a).

With regard to the tsunami sedimentary evidence in the Portuguese coast, and according to Abrantes et al. (2005) the energy of this tsunami at the mouth of Tagus River, in Lisbon, was estimated to have eroded $160-355$ years of the sedimentary marine record and instantaneously deposited a $19 \mathrm{~cm}$ sediment bed consisting of a lower layer of silt sized heavy mineral particles, followed by a coarser layer composed of reworked shell fragments.

Of all the sedimentary records known from the 1755 tsunami, the most thoroughly studied was the one at Boca do Rio, west of the Portuguese Algarve (Dawson et al., 1995; Hindson et al., 1996; Hindson and Andrade, 1999; Oliveira et al., 2009; Font et al., 2010). Boca do Rio is an estuarine supratidal flood plain that before the 1755 tsunami was separated from the sea by a barrier that prevents wave overtopping during storms (Hindson and Andrade, 1999):

The tsunami deposit (Unit B) could be locally expressed as a complex unit composed of five sub-units with different sedimentary features. Its tsunamigenic origin was interpreted considering the thickness $(<0.45 \mathrm{~m})$ and extent of the sand tabular unit, the coarse size of sediment (sand and gravel) contrasting with estuarine fine silty clays, the presence of clay balls from the surface erosion of the estuary mud-flats, the presence in the deposit of different marine species in an estuarine depositional environment and the presence of boring boulders (Hindson and Andrade, 1999). Luminescence and radiocarbon dating allow the identifying of the unit B as a result of the 1755 tsunami (Dawson et al., 1995; Hindson and Andrade, 1999; Cunha et al., 2010). It was also possible to determine a run-up of up to $7 \mathrm{~m}$ in the area by numerical simulation (Font et al., 2010).

In addition to Boca do Rio, similar deposits in other regions of the Portuguese Algarve were studied, specifically in Martinhal and Ria Formosa (Andrade, 1992; Andrade et al., 1994, 1997, 1998; Kortekaas and Dawson, 2007). These deposits consist of sand sheets from beaches and barriers of cobbles and boulders on the sheltered muddy intertidal salt marsh.

Similarly, the turbidites deposited on the abyssal plains, SW off Portugal (SW of Cape St.Vincent) were the subject of diverse studies (Lebreiro et al., 1997; Vizcaino et al., 2006; García Orellana et al., 2006; Gràcia et al., 2010). Several turbiditic units have been differenti- 
ated among hemipelagic deposits and debris flows, which are mostly interpreted as a result of the seismic activity in the area. Eleven turbiditic events have been differentiated within the Holocene from which seven may be regarded as seismically triggered events. Some of them, dated by calibrated AMS, have been correlated with the dates of important historical earthquakes and palaeotsunami deposits in the Gulf of Cádiz, such as AD 1755 and 218 BC (Gràcia et al., 2010). The thickness of each turbidite does not show a correlation with the intensity of the earthquake, because there are other factors to be considered, such as sediment availability and stability conditions in the source area. So the AD 1755 Lisbon earthquake triggered only a thin turbidite $(<20 \mathrm{~cm}$ thickness near the Mârques de Pombal fault) (Vizcaino et al., 2006). This turbidite has been studied and identified by Thomson and Weaver (1994), Lebreiro et al. (1997), Abrantes et al. (2005) and Vizcaino et al. (2006).

\subsection{Spanish coast}

There was an extended destruction in the villages and cities along the Spanish south Atlantic coast. In the west, the city of Huelva was probably the one that suffered most damage by the earthquake and subsequent tsunami (IGN, 2005). The number of victims from the event was estimated to be over 1000 . The tsunami waves inundated the marsh surrounding most of the city, and it propagated travelling roughly a distance of about 2 leagues $(\sim 11 \mathrm{~km})$. The rise of the Odiel River, which delimits the west of the city, caused the flooding of streets and squares. There were three remarkable waves that produced extensive inundation and the waters flowed with extraordinary movement for $24 \mathrm{~h}$.

In the city of Cádiz, it was estimated that the wave height could have reached 15-19 $\mathrm{m}$, according to the chronicles of that time (Blanc, 2008). However, these sources are reexamined in that study and it is concluded that the wave height values could have not been that high. Thereby, the amplitude accepted would be around $2.5 \mathrm{~m}$, which added to the drawdown means that the full amplitude must have been about twice that amount. Furthermore, it must be considered that the first wave arrived with a speed of more than $30 \mathrm{~km} \mathrm{~h}^{-1}$, causing a run-up phenomenon. Independently, the wave swept and crossed the tombolo that links Cádiz to the peninsula, killing all the people that tried to leave the city through this route.

Most historical data in this coastal zone concern the village of El Puerto de Santa María, located on the northern side of the Bay of Cádiz. A report of the Real Academia de la Historia cites waves of up to $8 \mathrm{~m}$ in height which destroyed the harbour and scattered numerous boats around the village and the surrounding fields (Luque et al., 2001).

As for the deposits associated with the tsunami, these were located and studied in various points of the coast of Huelva, but mostly in the coast of Cádiz. Thus, in the area of Huelva, Morales et al. (2008) found a lumachellic high-energy layer, composed of clean sand, with a variable content of whole shells and shell fragments, quartzite pebbles, and muddy clasts. The authors interpreted this layer as "the sedimentary results of the dissipation of the tsunami wave after the AD 1755 Lisbon earthquake". However, the calibration of radiocarbon dating shows some errors that should be reviewed (Rodríguez-Vidal et al., 2009).

In Doñana National Park, Lario et al. (2001) detected sandy levels among the fine materials that fill the Guadalquivir wetlands. The study of these materials in various probes by statistical analysis of grain size and magnetic properties reveals the existence of some episodes associated with high-energy conditions (storms, floods and tsunamis). This material would come from the input of coarse sediments into the inner estuary during this infilling phase due to the energetic events. Some of the most recent episodes identified are linked to the 1755 tsunami.

In the coast of Cádiz, Dabrio et al. (1998) detected some spill fans on the Valdelagrana spit barrier (Bay of Cádiz) and ascribed them to the tsunami of 1755. These are several washover fans connected to the inland side of the spits. These deposits consist of fine quartz sands, similar to the coastal ridges and aeolian dunes, plus pebbles (basal unit), fragmented shells and plants remains, and the sand at the top is interbedded irregulary with layers of silty clay. They represented fining-upwards sequences that occurred three or four times, including up to 4 units in each sequence. Those washover fans are 3-4 $\mathrm{m}$ above the high tide level and the thickness of the sand units range between 1.2 and $0.5 \mathrm{~m}$ but they wedge out landwards. This configuration could reflect the different conditions during the run-up and backwash of several tsunami waves. The marine origin of these deposits is demonstrated by the faunal content and their morphology (Luque et al., 2001). The energy released by the tsunami wave was strong enough to overtop and erode an important amount of sand from the littoral dune and mixed it with reworked materials from underlying layers at least one meter in depth. However, Gracia et al. (2006) questioned the ascription of these deposits to the 1755 tsunami and state that the effects of the event on this low coast probably consisted of coastal lowering and spit breaching with the development of inflow washover fans and channels that affected mainly the Valdelagrana spit barrier. 
Other washover fans are described in the Cádiz coast and they are interpreted as a result of the 1755 tsunami. In Conil, Luque et al. (2004) described two which contained construction fragments from houses destroyed by that event. In Los Lances Bay, near Tarifa, washover fans (up to $100 \mathrm{~m}$ length and $30 \mathrm{~m}$ width), which cut through Holocene beach ridges and are disconnected from the present-day beach-dune system (Gracia et al., 2006) were also described. In this area, there is an $18^{\text {th }}$ century bridge that is partially destroyed. The distribution of erosion/accumulation zones around the bridge suggest that it acted as an obstacle to the tsunami waves like a huge flute mark (Gracia et al., 2006).

In this coastal area (between Barbate and Tarifa), Koster et al. (2009) found tsunamigenic deposits on the rocky cliffs of Barbate and Zahara de los Atunes, also in Los Lances and, eventually, in the wetlands of Barbate. These are basically fining-up sequences from coarse grains and boulders partly imbricated into fine clays, with rising magnetic susceptibility upwards, and unsorted pebbly layers containing mainly shell debris. In wetland environments, the most characteristic sediments are mixtures of sand beach-boulders-shells-clayey marsh. The presence of deep water foraminifera transported by the tsunami waves is also common. These authors interpret these deposits as a possible consequence of the AD 1755 tsunami, despite the absence of absolute dating.

A few miles south of Cádiz, before reaching the SanctiPetri spit, there are deposits that form a sheet (1-1.4 m. thick and 2-2.5 $\mathrm{m}$ a.s.1.) composed of flat rounded imbricated cobbles and shell fragments. These fossilized deposits date from the $17^{\text {th }}$ century and may be a consequence of the 1755 tsunami. There are also isolated blocks and fields of blocks within this area that could be ascribed to the same event regarding archaeological remains (Gracia et al., 2006).

The accumulations of boulders and imbricated blocks are evident in Cape Trafalgar. There are several types of block clusters at different heights in this area. About 80 blocks are arranged on a coastal platform at about 100 $\mathrm{m}$ from the coastline and around $1 \mathrm{~m}$ a.s.1. Other rocks (beetwen 0.2-1.5 $\mathrm{m}$ diameter) form parallel ridges of imbricated blocks up to $6 \mathrm{~m}$ a.s.l. Many other blocks under $0.4 \mathrm{~m}$ in length spread landward forming a field of blocks about $100 \mathrm{~m}$ wide with a typical fan shape. This evidence is associated with the 1755 event through indirect methods and were described and studied by Alonso et al. (2004), Gracia et al. (2005) and Whelan and Kelletat (2005). There are other fields of imbricated blocks southward, in Bolonia Bay, with 0.3-0.4 m length and between 2-3 $\mathrm{m}$ a.s.1. Likewise, they are interpreted as being associated with the same event, despite the absence of absolute evidence (Gracia et al., 2006).

The effects of this tsunami upon the coastline of the Strait of Gibraltar have not been studied, but there are historical records (James, 1771) of its impact upon the harbour and shipping at Gibraltar. In terms of geological record, evidence in three areas for three different environments, beach-coastal barrier, cliff and submerged platform, is shown in this study.

\section{Methodology and sampling}

The study of the 1755 tsunami evidence in Gibraltar was performed in three different areas of the Rock. Since they belong to different environments, different work methodologies were required for these three sectors.

\subsection{The Inundation lagoon}

The Inundation is an old coastal lagoon, with a sedimentary record of at least $4000 \mathrm{cal} \mathrm{yr} \mathrm{BP}$ (table 1) in the isthmus of Gibraltar (C in Fig. 1B and Fig. 2A). This isthmus is the tombolo that links the Rock with the mainland and it is occupied by diverse buildings and infrastructures, e.g. the airport, in the present day. Therefore, the lagoon no longer exists, but it can be seen in diverse historical maps and photographs. The aim of studying this area is to find evidence that the tsunami broke the western sand barrier, which kept it away from the open sea (Bay of Algeciras/Gibraltar), and must have dragged material from the barrier and offshore sediments. For this study we had access to cores that had been bored by the geotechnical company Sergeyco Andalucía S.L. for the airport expansion works. Specifically, the BH-2 core, which reaches $12.5 \mathrm{~m}$ depth, was used. Within the last $3 \mathrm{~m}$ of this core, those levels corresponding to the natural filling were analyzed (Fig. 2B). It is within this section that the transit that indicates the input of material carried by the tsunami appears. Five samples were collected for textural and palaeontological analyses.

Facies analysis on sediment of the core was performed to characterise the sedimentary record. Due to the predominance of detrital facies, the lithological description has been complemented with a grain-size analysis of all the samples collected (Fig. 2C). Grain-size distribution was determined by wet sieving for the coarser fractions $(>100 \mu \mathrm{m})$. Fractions under $100 \mu \mathrm{m}$ were analyzed by photosedimentation (MicromeriticsR SediGraph 5100 ET). Na-hexametaphosphate was used as a dispersing agent.

The macrofossil record of five sub-samples was obtained by washing the bulk sediment through a 1-mm sieve. Molluscs were identified to species level. In ad- 
dition, other sub-samples were selected for microfossil analysis. These sub-samples were washed through a 63$\mu \mathrm{m}$ sieve to remove the mud fraction and then dried. Foraminifera were identified, but ostracods were not found.

Eventually, two samples with organic matter were extracted for radiocarbon dating (AMS). These samples were collected from the lower section at $3.00 \mathrm{~m}$ and 2.15 $\mathrm{m}$ depth respectively and, were carried out at Beta Analytic Laboratory (Miami, USA). The data were calibrated using IntCal09.14c (Reimer et al., 2009) calibration dataset. The final results correspond to calibrated ages (cal) using 2 sigma intervals and will be expressed as the highest probable age of the 2 sigma calibrated range.

\subsection{Rosia Bay}

The cliff sector where the tsunami evidence was found is the region known as Rosia Bay, at the western side of the Rock ( $\mathrm{R}$ in Fig. 1B). In this area, there are some open crevices in the cliff wall and they are mostly filled with sediments that can be adscribed to different energetic events (Fig. 4). The characteristics of the infill were described during field study. A systematic sampling of sediments and marine faunal debris was also performed. All samples were referenced to the local marine environment level (Datum). Sediments were subjected to grain size analysis, using the same methodology as $\mathrm{BH}-2$ core, and marine fauna debris were identified and dated by radiocarbon (AMS). The latter was carried out at the Centro Nacional de Aceleradores of Seville (CNA), Spain.

\subsection{Vladi's Reef}

Finally, the evidence on the submerged platform was found south of Europa Point, in a group of small undersea caves located at $22 \mathrm{~m}$ depth (V in Fig. 1B). The project "Underwater Archaeological Excavations (GIBRAMAR Project)" was performed in this area in 2005 and during the archaeological works numerous samples of the infill of these undersea caves were extracted. For this paper we analyzed the faunistic content, bioerosion and grain size of these samples, and in addition, two marine faunal samples were subjected to absolute dating by AMS, for which they were sent to the Oxford Radiocarbon Accelerator Unit (U.K.).

The methodology used in the study of macro and microfauna was the same as for the samples of the Inundation lagoon, but in this case some ostracods were found. The bioerosion was determined by visu analysis of hand samples or with the aid of a binocular microscope.

Independently, the samples for grain size analysis (Fig. 5C) were dried at room temperature and sieved through a $2 \mathrm{~mm}$ sieve to remove large particles. The particle-size distribution of sediments under $2 \mathrm{~mm}$ was performed using a Malvern Mastersizer 2000 (Malvern Instruments Ltd.). Particle sizes were determined for particle diameters between 0.02 and $2000 \mu \mathrm{m}$, which comprise the proportion of sand $(<2000-63 \mu \mathrm{m})$, silt $(63-4 \mu \mathrm{m})$ and clay $(<4 \mu \mathrm{m})$. Each sample was measured at 10 to $20 \%$ obscuration for 20-30 seconds, breaks of 10 seconds and repeated three times under moderately high pump and stirrer settings (1500-3000 rpm).

\subsection{Methodology and calibration of radiocarbon marine date}

Radiocarbon dates on marine samples have not been used as extensively as terrestrial biosphere ones (e.g., charcoal or bone) for the setting up of absolute chronologies. This is due to the fact that several oceanographic factors complicate their callibration. To set up chronologies for a particular coastal area using marine samples, previous research concerning the oceanographic conditions and the marine reservoir effect for that coastal area is needed in order to obtain accurate and reliable results.

The variability of the marine radiocarbon reservoir effect in the Gulf of Cádiz, and consequently of the upwelling phenomenon in the same region, during the Holocene, has been and is underway (Soares and Dias, 2006). Recent research concerning the reservoir effect in the coastal waters off the Gulf of Cádiz (Andalusian coast) suggests a significant fluctuation with time in $\Delta R$ values during the Holocene (Soares and Martins, 2010). During the Late Holocene, the eastern coast of the Gulf of Cádiz is characterized by the absence of an active upwelling as is the case today. A calculated weighted mean for $\Delta R$ is $-135 \pm 20{ }^{14} \mathrm{C}$ yr $(2400-200 \mathrm{BP})$.

The radiocarbon dates were converted into calendar dates using Marine09 calibration curves (Hughen et al., 2004; Reimer et al., 2009) for marine samples. The final results are expressed as calibrated ages for $2 \sigma$ intervals (Table 1).

\section{Local AD 1755 tsunami record}

\subsection{Historical news in Gibraltar}

An historical account of the effects of the Great Tsunami of Lisbon on the coast of Gibraltar is provided by Lieutenant T. James (1771) in his book on the coasts of the Strait and its surrounding regions: "This earthquake, perceived at Gibraltar, was in the forenoon on the first of November one thousand seven hundred and fifty-five, it began with a trembling which lasted half a minute, then 

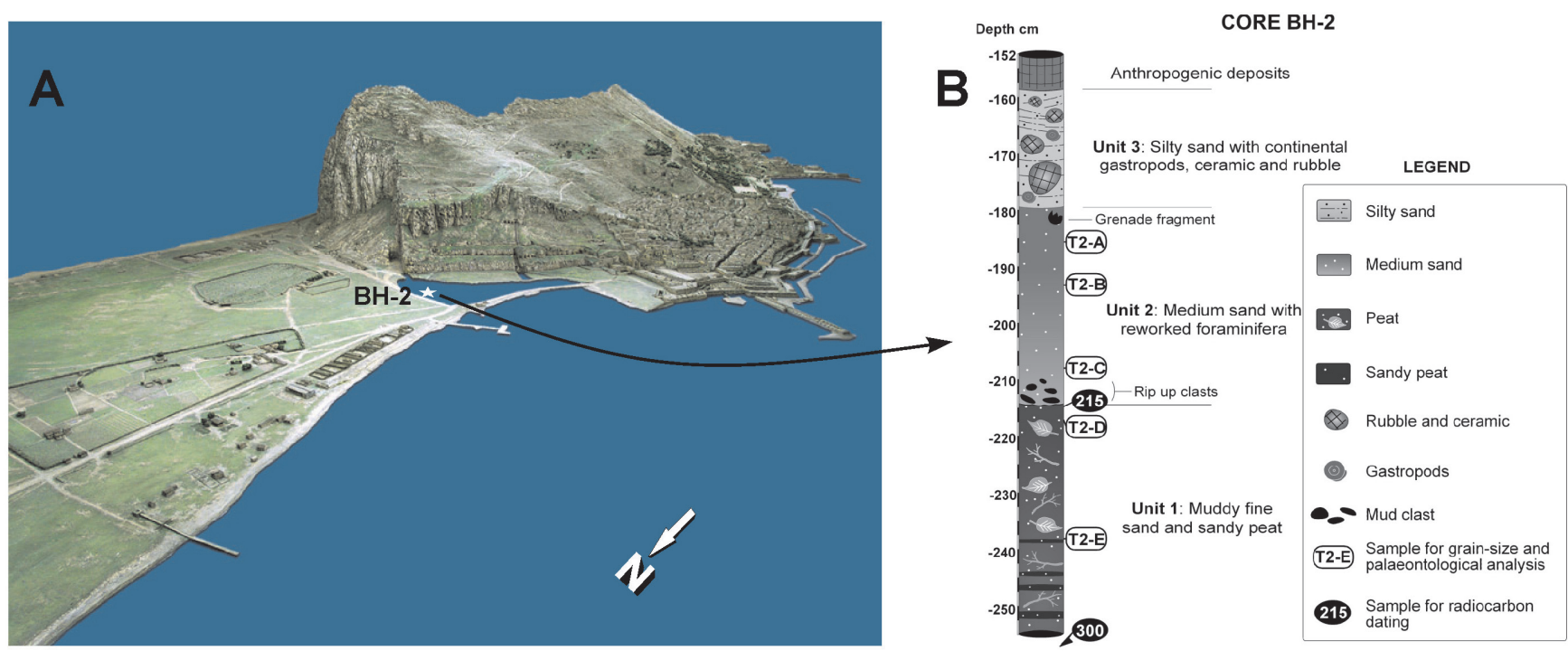

C

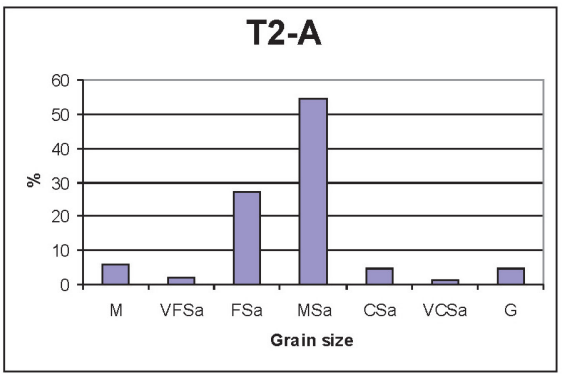

Unit 2

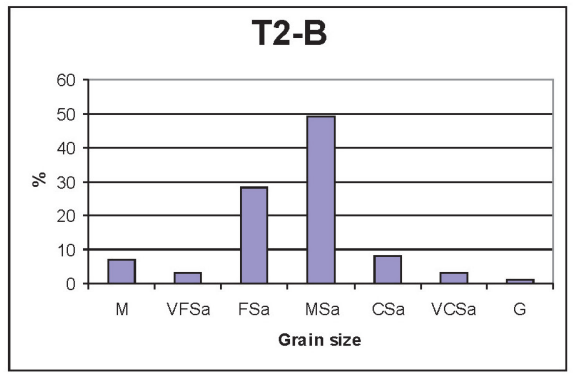

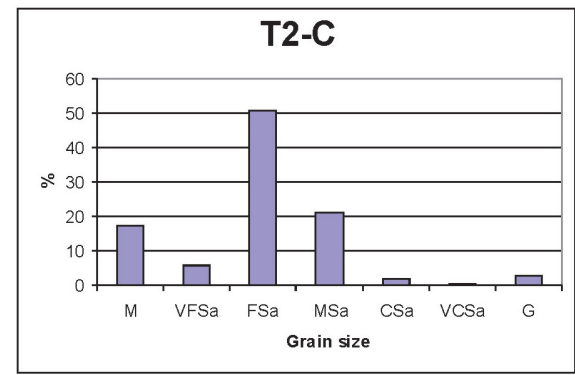

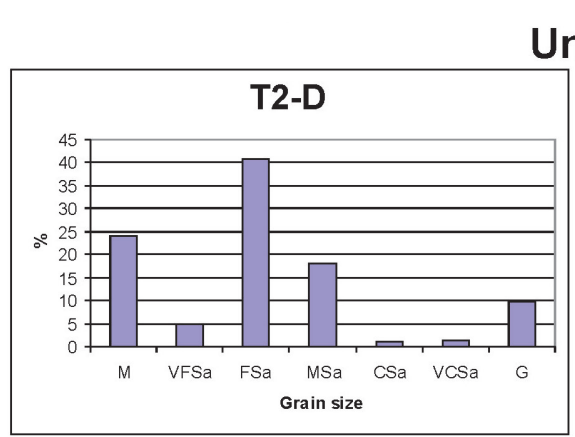

Unit 1

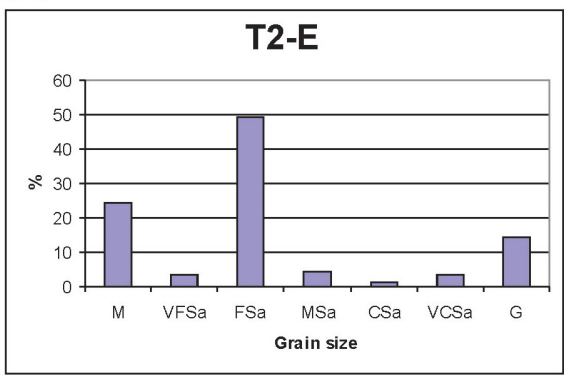

Fig. 2.- The Inundation lagoon area (C in Fig. 1B). A. Oblique view of the Rock of Gibraltar, with a good perspective of the lagoon and the BH-2 borehole. Figure based on the three-dimensional model realized by Lt. Charles Warren (1865-1868), the Gibraltar Museum. B. Core $\mathrm{BH}-2$, detrital facies and location of the samples taken for grain-size and dating analysis. C. Grain-size distribution of samples: bar-diagrams (M, muds (clay and silt). VFSa, very fine sand. FSa, fine sand. MSa, medium sand. CSa, coarse sand. VCSa, very coarse sand. G, gravel). Unit 2 (T2-A, T2- B and T2-C) and Unit 1 (T2-D and T2-E).

Fig. 2.- Zona de la laguna Inundation (C en la Fig. 1B). A. Vista oblícua del Peñón de Gibraltar, con una buena perspectiva de la laguna y del sondeo BH-2. Figura basada en el modelo tridimensional realizado por el teniente Charles Warren (1865-1868), Museo de Gibraltar. B. Testigo de sondeo BH-2, facies detríticas y localización de las muestras tomadas para el análisis granulométrico y para las dataciones. C. Granulometrías de las muestras: diagramas de barras (M, fangos (arcilla y limo). VFSa, arena muy fina. FSa, arena fina. MSa, arena media. CSa, arena gruesa. VCSa, arena muy gruesa. G, grava). Unidad 2 (T2-A, T2-B y T2-C) y Unidad 1 (T2-D y T2-E).

a violent shock, and went off gradually as it began; the sea rose every fifteen minutes six feet eight inches, and fell so low that boats and all the small craft near the shore were left aground, as were numbers of small fish; and on the third, fourth and fifth of the said month, small shocks were felt" (G in Fig. 1B).
This means that in the harbour area and possibly within the adjoining Bay, the height of the 1755 tsunami wave reaching the coast was only $2 \mathrm{~m}$ a.s.l. (black solid line in Fig. 1B). The former coastal lagoon (The Inundation), immediately north of Gibraltar, must have flooded as a consequence of the tsunami waves (white dotted line in 


\begin{tabular}{|c|c|c|c|c|c|c|}
\hline Field code & Lab. code & Material & $\begin{array}{c}\text { Elevation } \\
\mathbf{m} \pm \text { p.s.l. }\end{array}$ & ${ }^{14} \mathrm{C}$ age $^{\mathrm{a}}$ & $d^{13} \mathrm{C} \%$ & $\begin{array}{c}2 \sigma \text { range } \\
\text { cal BP age }^{b}\end{array}$ \\
\hline $\mathrm{BH} 2 \mathrm{M} 215$ & Beta-290903 & peat & -2.15 & $2680 \pm 30$ & -28.0 & $2750-2850$ \\
\hline $\mathrm{BH} 2 \mathrm{M} 300$ & Beta-290904 & peat & -3.00 & $3770 \pm 40$ & -27.9 & $3980-4290$ \\
\hline GB0804 & CNA136 & shell & +5.40 & $460 \pm 45$ & 1.4 & $72-360^{\mathrm{c}}$ \\
\hline VLA047 & OxA15864 & shell & -22 & $491 \pm 22$ & 0.9 & $179-360^{c}$ \\
\hline VLA044 & OxA15824 & encrustation & -22 & $907 \pm 27$ & 1.4 & $541-667^{\mathrm{c}}$ \\
\hline
\end{tabular}

Table 1.- Database of ${ }^{14} \mathrm{C}$ samples (marine and peat) and calibrated ages. Laboratory: (Beta) Beta Analytic laboratory, MiamiUSA, (CNA) Centro Nacional de Aceleradores, Sevilla, Spain, (OxA) Oxford Radiocarbon Accelerator Unit, U.K. Sample location: (BH) The Inundation lagoon, core BH-2, (GB) Rosia Bay cliff, (VLA) Vladi's Reef. (a) AMS analysis, (b) IntCal09.14c (Reimer et al., 2009), (c) $\Delta R=-135 \pm 20{ }^{14} \mathrm{C}$ years (Soares and Martins, 2010).

Tabla 1.- Base de datos de muestras radiocarbónicas (marina y turba) y edades calibradas. Laboratorios: (Beta) Laboratorio Beta Analytic, Miami, EEUU, (CNA) Centro Nacional de Aceleradores, Sevilla, España, (OxA) Unidad de Aceleradores de Radiocarbono de Oxford, Reino Unido. Localización de las muestras de campo: (BH), laguna The Inundation y sondeo BH2, (GB) acantilado de Rosia Bay, (VLA) arrecife de Vladi. (a) analisis de AMS, (b) edad calibrada mediante IntCa109.14c (Reimer et al., 2009), (c) $\Delta R=-135 \pm 20$ años de ${ }^{14} \mathrm{C}$ (Soares y Martins, 2010).

Fig. 1B), although there is no stratigraphic record as it is currently filled with debris and covered by buildings.

\subsection{The Inundation lagoon record}

\section{Historical cartography}

As mentioned earlier, the Inundation lagoon does no longer exist. However, its existence and evolution may be followed from the historical cartography (Fig. 2A), which is available for consultation at the Gibraltar Museum.

The oldest map that shows the geography of the region dates from 1627 and was drawn in order to chart the Spanish defenses. The lagoon, completely enclosed and isolated from the open sea by a coastal barrier, is already present in this document. A similar situation is shown in a map from the following century (1726). Therefore, it was a fresh water lagoon at least for more than 100 years and it was very probable that peat was being formed at the bottom.

Later maps from 1738, 1744 and 1753, show that the coastal barrier had only one natural exit towards its southern end and a transversal artificial rupture further north. Therefore, since it was connected with the sea, the lagoon water would be brackish and peat formation stopped.

The next map available is from 1760, 5 years after the Lisbon tsunami. In this map, the coastal barrier shows an artificial rupture that is very close to the town of Gibraltar, at the entry gates of the city. The outer beach is screed in width and does not show a washover-fan inside the lagoon; thus, the tsunamite was deposited at the bottom of the lagoon.

In the mid $19^{\text {th }}$ century, specifically in 1865 , the lagoon rupture appears closed again with the access road to Gibraltar running above it; therefore, the enclosure was artificial.
Photographs of the area from the early twentieth century, some of which predate the airfield construction (Second World War), show that the anthropic filling was already present in the boring area, although a part of the lagoon remained intact. Later, during the construction of the runway, the road that extends to the W-SW (Devil's Tower Road) was defined, as were the artificial fillings northward and southward, which silted the lagoon up.

\section{Core $\mathrm{BH}-2$}

In addition to the cartographic analysis, it was possible to obtain access to the cores from several taken in the area, as mentioned above. From these, BH-2 (Fig. 2B) showed the best record, and was selected for the analysis of its facies and sequences. Three units have therefore been described within the firsts $3 \mathrm{~m}$ of this core. These are from bottom to top:

Unit 1 (300 $\mathrm{cm}$ to $214 \mathrm{~cm}$ depth): Massive, muddy fine sands rich in carbonaceous remains, with scattered coarser gravels of quartz. Lenses of sandy peat of a few centimetres thickness are common in their base. Mud percentage decreases upwards while the amount of medium sands increases slightly. Marine fauna have not been observed in these facies.

Unit 2 (214 cm to $178 \mathrm{~cm}$ depth): Inversely graded fine to medium sands, very well sorted, with scarce muddy matrix and round to very round quartz grains. The basal contact of these sands is a sharp erosion surface draping by irregular clasts of peat derived from the underlying facies. A few specimens of Pliocene foraminifera have been found in this facies (Heterolepa bellincionii Giannini y Tavanni, Cibicides floridiana Cushman, Sphaeroidina bulloides d'Orbigny, Ammonia beccari Linné, Elphidium crispum Linné), probably reworked from the 


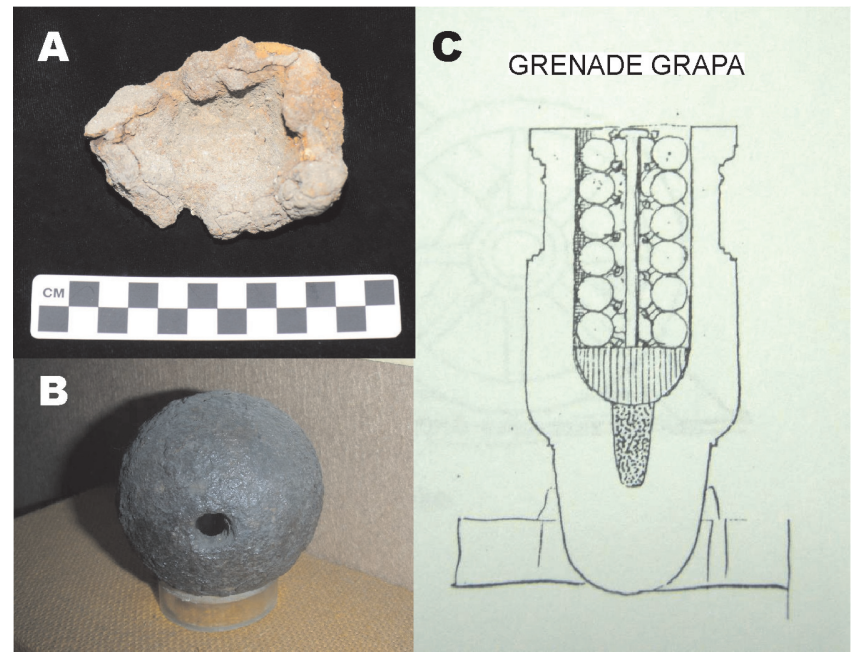

Fig. 3.- Hand grenade. A. Grenade fragment found in the top of Unit 2. B. Photograph of a 6-pounder grenade from the Great Siege ( $18^{\text {th }}$ century) in the Gibraltar Museum. C. Mortar prepared to fire grenade grape, reproduced from Rollo (1989).

Fig. 3.- Granada de mano. A. Fragmento de la granada encontrada en el techo de la Unidad 2. B. Fotografía de una granada de 6 libras procedente del Gran Asedio (siglo XVIII), en el Museo de Gibraltar. C. Mortero preparado para disparar un racimo de granadas (Rollo, 1989).

sandy cliffs located to the north. Remains from a hand grenade were found at the top of this unit (Fig. 3A); its analysis will provide chronological data of this unit. A detailed analysis of this type of projectile will be shown below.

Unit 3 (178 $\mathrm{cm}$ to $0 \mathrm{~cm}$ depth): Brown to reddish silty sands, with ceramic fragments and rubble of anthropic origin, carbonaceous remains and well-preserved continental gastropods.

\section{Grenade fragment}

The projectile fragment, found in top of Unit 2 (Fig. $3 \mathrm{~A}$ ), is large enough to directly measure its approximate diameter and thickness, and these correspond extremely well with a 6-pound hand-grenade. This type of grenade was in use during the $18^{\text {th }}$ century, usually carried by 'Grenadiers' who in most armies were elite troops (Fig. 3B). Grenade use fell from favour towards the end of the $18^{\text {th }}$ century, only to re-emerge in the mid- $19^{\text {th }}$, but by then grenade designs had changed considerably.

The fragment edges were heavily oxidised indicating that the breaks were not recent, but rather most likely occurred when the fragment fell to the ground. The possibility that this was a peacetime event is minimal given that during non-bellicose intervals, armaments needed to be accounted for and would most likely have been recovered.
The most probable scenario is that the object arrived there during a hostile engagement. The $18^{\text {th }}$ century offers three possibilities: the Anglo-Dutch capture of Gibraltar and the ensuing $12^{\text {th }}$ siege $(1704-1705)$, the $13^{\text {th }}$ siege of 1727 and the $14^{\text {th }}$ siege, more commonly known as the Great Siege (1779-1781). Although Prince George of Hesse d'Armstadt did land marines on the isthmus during the 1704 capture, it is unlikely that hand grenades would have been used as they needed to be physically thrown (range was around $30 \mathrm{~m}$ ), and there are no defences recorded in that area at the time. Therefore, the greater likelihood lies in the 1727 and 1779-1783 sieges as there were advanced Spanish positions in that area. No references have been found for usage of grenades in the area during the 1727 siege, and the greater likelihood therefore lies in the Great Siege. Based on Rollo (1989), there are two likely possibilities via which a grenade might have ended up in that location:

i) That the grenade arrived via a mortar shot (grenade grape fired from a cannon from British positions on the Rock, a technique developed during that siege), or

ii) That it was hand-thrown by a Grenadier (most likely during the Great Sortie of November 1981, where a number of Grenadier regiments were involved in that precise area).

In either case it ties down the date to the Great Siege so the hand-grenade is almost certainly from the $18^{\text {th }}$ century (given known time limits of usage), with a significantly higher-than-average likelihood that it dates from the 1770-1780s. Further excavations in the area may produce more similar fragments which will support the argument in favour of the possibility that the presence of the projectile is as a result of bellicose activity.

\section{Results for The Inundation lagoon}

Regarding the $\mathrm{BH}-2$ core, it is possible to make the following considerations, which may be extended to the whole area.

Unit 1 was formed in a low energy and relatively confined continental environment - the closed lagoon - on the basis of particle size (Fig. 2C), high concentration of organic matter and absence of marine fauna. Both the accumulation of organic matter of vegetable origin and the input of wind-derived, terrigenous sediments from backshore areas located immediately toward the North dominated in this environment.

Unit 2 recorded an episode of rapid infilling of the system through a high-energy event that eroded the underlying organic-rich sediments and incorporated them (rip up clasts) within a large volume of sands transported from adjacent coastal areas and sandy Pliocene outcrops. The 
appearance of the hand grenade fragment in top of this unit in the 1770-1780's allows fixing the age of the deposit to an immediately previous moment. Therefore, the energetic event that Unit 2 could generate would be the 1755 tsunami. Evidence of similar deposits have been described for India where sand deposits without organic matter content and even material dragged from the continent by the backwash (Srinivasalu et al., 2010) have been recorded.

Finally, Unit 3 recorded the colmatation of the pond by means of both anthropic activity (mainly) and natural sedimentary dynamics of the system.

In addition, two radiocarbon datings were obtained from the basal unit of core BH-2 (Fig. 2B and Table 1), so a continuous sedimentary record can be observed between $3 \mathrm{~m}$ depth (cal. 4290 BP-3980 BP) and $2.15 \mathrm{~m}$ depth (cal. 2850 BP-2750 BP). Consequently, the upper $85 \mathrm{~cm}$ of Unit 1 were deposited from about 1300 years and a mean sedimentation rate of $\sim 0.65 \mathrm{~mm} / \mathrm{yr}$ can be inferred.

According to the historical maps that were analyzed, the lagoon was isolated from the sea at least until 1738, when natural and artificial openings of the lagoon are registered. Thus, peat must have formed at its bottom until that date. The dating of the top of Unit 1 in the probe record provides an age of cal $2850 \mathrm{BP}-2750 \mathrm{BP}$, which involves intense and rapid erosion of the upper section of that unit, possibly due to the tsunami. The sedimentation rate calculated above can be used to estimate the erosion caused by the tsunami in this area. The lack of deposition between the upper part of Unit 1 and the end of the sedimentation (1738) is about 1000 years. If the sedimentation rates of the basal unit were extrapolated to this period, the 1755 tsunami caused the erosion of $\sim 65 \mathrm{~cm}$ of Unit 1 and the deposition of $35 \mathrm{~cm}$ (Unit 2).

The data above indicate that erosion of the 1755 tsunami $(\sim 65 \mathrm{~cm})$ would approximately double the subsequent deposition $(35 \mathrm{~cm})$. These proportions are similar to those estimated by Abrantes et al. (2005) off Lisbon (Portugal), where this tsunami caused the loss of $39 \mathrm{~cm}$ of sediment and the instantaneous deposition of a $19 \mathrm{~cm}$ sediment bed.

Different erosion/deposition rates have been estimated for other recent tsunamis with different results. In Kirinda Harbour (Sri Lanka), the first run-up tsunami wave of the 2004 Indian Ocean tsunami deposited a 4 m thick layer along the shoreface slope (Goto et al., 2011). On the other hand, the AD 1969 tsunami caused the deposition of a thick turbidite $(5-8 \mathrm{~cm}$ thickness) off the Tagus

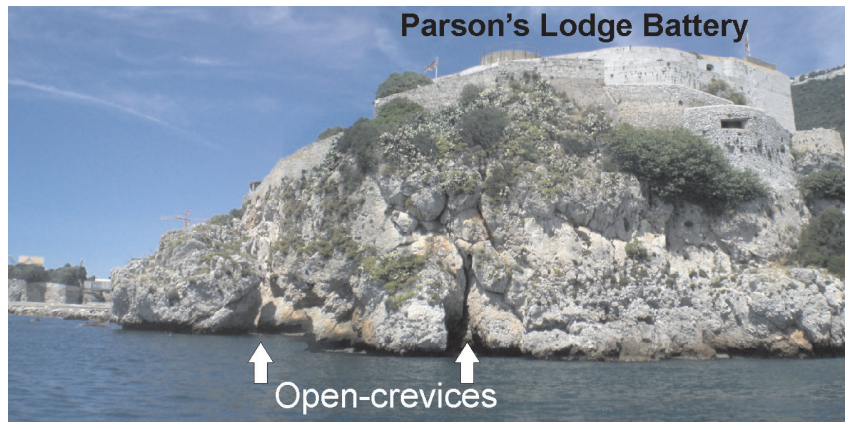

Fig. 4.- Rosia Bay site (R in Fig. 1B) and its Parson's Lodge southern flank. Extensional open-crevices partially filled by tsunami sediments.

Fig. 4.- Bahía de Rosia ( $\mathrm{R}$ en la Fig. 1B) y el flanco sur de la fortaleza de Parson. Grietas extensionales abiertas y parcialmente rellenas de sedimentos tsunamigénicos.

River mouth, near Portugal (Abrantes et al., 2008).

Other interesting data that could be derived from the historical cartography and probing is that the flooding of the tsunami wave in the isthmus must have reached a maximum distance of $200 \mathrm{~m}$ and the sandy sediment dragged by the washover travelled up to $100 \mathrm{~m}$ inland from the coast line.

\subsection{Cliffed coast evidence}

On the rocky outcrop which forms the southern flank of Rosia Bay and upon which Parson's Lodge Battery sits, a number of south-oriented open-crevices are visible (Fig. 4), where we have discovered sedimentary accumulations associated with various energy events ( $\mathrm{R}$ in Fig. 2).

These deposits exhibit a bimodal granulometry and are composed of siliceous sands and bioclasts with gastropod and bivalve shells and other marine faunal remains, together with angular dolomite fragments derived from the faces of the crevice. Depending on age, deposits are more or less compacted, cemented or covered with a thin flowstone layer.

Although this coastal zone was artificially scarped by the British Military for defensive reasons, this did not take place until shortly after the tsunami: “... on the SW, side of Rosia Bay, was discovered, in the year 1769, a huge mass of petrifactions of a very singular kind. The workmen who were employed in scarping the face of the rock to render it less accessible, after having wrought, by mining, through about ten feet of solid limestone came to a vast congeries of bones, blended and consolidated together in a confused manner with limestone of various sorts, freestones, spars, selenites, stalactites and calcareous crystallizations and incrustations ..." (after White, 
1913). It was this engineering activity that led to the discovery of the historic Quaternary fossil "Rosia Bay bone breccia”.

\section{Results for Rosia Bay}

The sediments that fill up the cracks of the Rosia Bay cliff were interpreted to be a consequence of diverse high-energy events. The dating obtained from faunal debris in diverse filling levels permitted to correlate this event with several Late Holocene tsunamis ( < cal $3000 \mathrm{yr}$ BP, unpublished).

The highest above sea level evidence of the tsunami sediment can be found at $5.4 \mathrm{~m}$ above Gibraltar Chart datum and they consist of disarticulated valves of Chlamys sp., which have yielded a AMS date (cal 360-72 yr $\mathrm{BP}$, Table 1), and are indicative of the minimum height reached by the tsunami wave when it impacted the cliff below Parson's Lodge.

\subsection{Submerged Vladi's Reef record}

A less evident record of the effects of the tsunami, although not less significant, can be found $\sim 22 \mathrm{~m}$ below the surface of the sea, south of Europa Point, on a submerged platform (Vladi's Flat). Along its southern border a small rocky ridge (Vladi's Reef, after Flemming 1972) can be seen with a number of small caves opening to the north (Fig. 5A-B). As from 2005, these caves have been the focus of underwater archaeological excavations (GIBRAMAR Project).

GIBRAMAR fieldwork programme was formulated to address two aims. First to identify the archaeological potential of the caves and shelters in Vladi's Reef and secondly, to investigate evidence of sea level fluctuations and still stands during the Quaternary, whereby addressing implications for human occupation and dispersal. Preconstructed sections of a uni-strut grid were passed to the seabed, moved to the area selected for excavation (Cave 7 or Momber's Cave) and assembled. This created a robust structure which would aid excavation and planning.

The reef drops from $-19.0 \mathrm{~m}$ at the top of the cliff to $-22.0 \mathrm{~m}$ at its north east limit (Fig. 5A). The foot of the reef was clearly defined at the edge of the boulder field, averaging about $18 \mathrm{~m}$ wide. A large expanse of sand lies beyond this, falling away gently to the north east.

The interior of the caves is covered with beach-worn cobbles with borings and encrusted marine organisms, which have provided a date range of cal 667-541 yr BP (Table 1). Covering these stones, and presently forming the sea bed, there is a fine sandy deposit, with numerous shell fragments that date to cal 360-179 yr BP (Ta- ble 1). From these deposits, we took the sample VLA047; although it is composed mostly of sand (Fig. 5C), it contains a high proportion of gravels and low proportion of silts and clays $(21 \%)$. The larger, coarser fraction is composed of bioclastic fragments and small subangular dolomite pebbles. Both of these have been affected by bioerosion (Entobia) and also the development of a localised ferruginous coating.

Regarding the faunistic component, macrofauna are very abundant, especially bivalves (fragments of Acanthocardia tuberculata, Venus pollastra and Venerupis romboides), and gastropods (Hinia reticulata, Bittium reticulatum and Natica alderi); as well as cheilostomatid bryozoans, echinoderm spines (probably cidaroidans), crab claws and fragments of balanid cirripeds. In contrast, the microfauna are not particularly abundant, with absence of planktonic foraminifera. Amongst those present, fragments of miliolids are common and occasional specimens of Ammonia beccarii, Elphidium crispum and Planorbulina mediterranensis were found. Some ostracod species present were Bairdia mediterranea (frequent), Loxoconcha rhomboidea (rare), Xestoleberis dispar (rare), Xestoleberis communis (rare), Urocythereis oblonga (frequent) and Aurila convexa (rare).

Results for Vladi's Reef

The caves and cavities along Vladi's Reef have acted as traps for sediments stemming from the plain immediately to their north. The lower and coarser materials were deposited during a period which the strong marine currents and storms in the area only allowed for the persistence of rolled pebbles and boulders.

Meanwhile, the last deposit (VLA-047) appears to have formed from the physical translocation of sediments from Vladi's Flats due to the backwash current. The high gravel content is interpreted as high-energy deposit, while the relatively low proportion of silts and clays indicate that the sediment was deposited in a high-energy environment. In this situation, finer sediments were transported away from the site but coarser grains steadily accumulated.

The macrofaunal and microfaunal assemblages found correspond to, and can be broadly associated with, welloxygenated coastal or shallow water environments that are adjacent to an open marine platform.

Thus, this deposit has been interpreted as a result of the AD 1755 tsunami. This material, trapped in the surface of these cavities may be considered as a subaqueous tsunami deposit. Sandy submarine tsunamites have been described for this same event in the continental platform in front of the mouth of River Tagus in Lisbon (Abrantes 

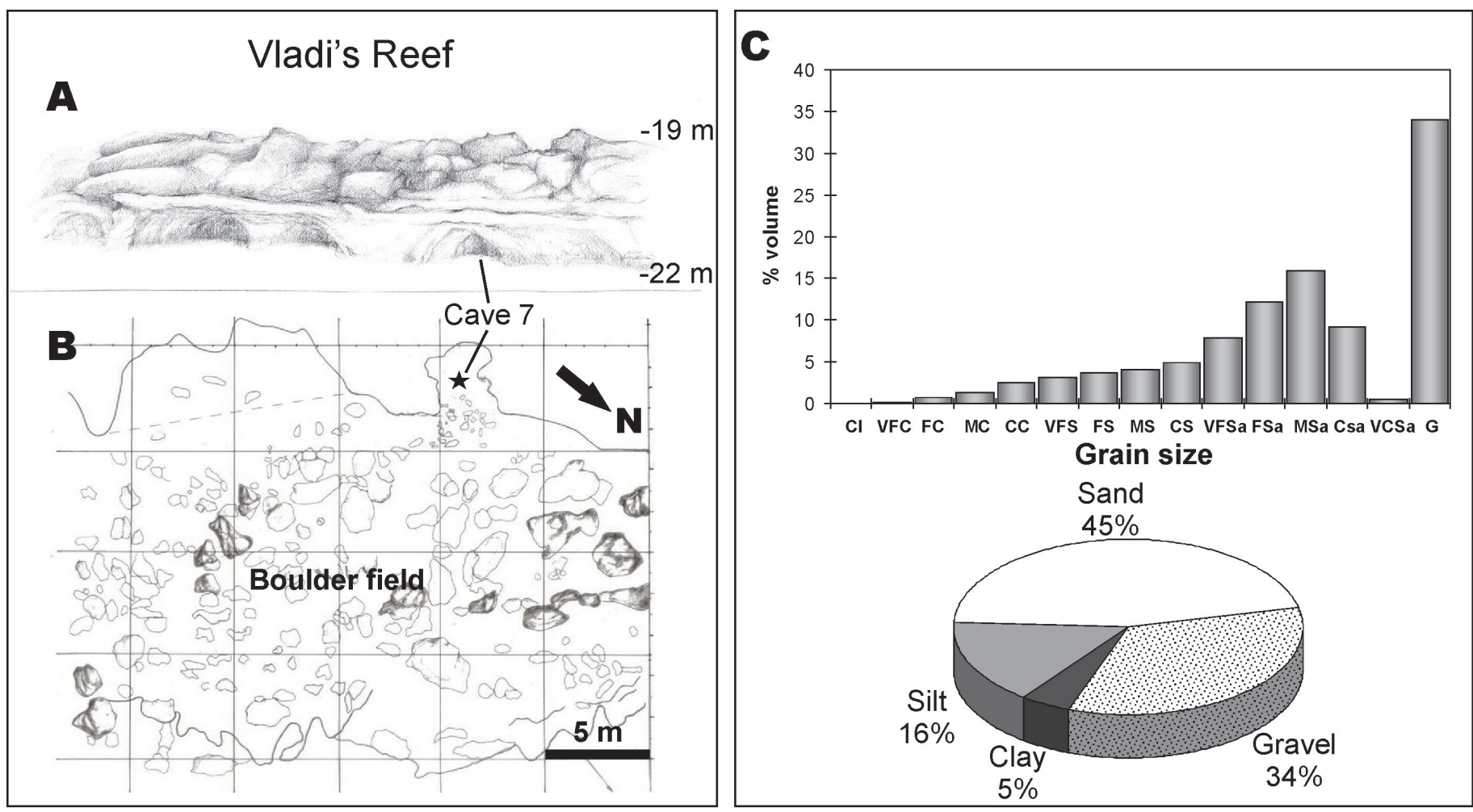

Fig. 5.- Vladi's Reef (V in Fig. 1B). A. Schematic profile of Vladi's Reef, with the rocky ridge elevation (from $-19 \mathrm{~m}$ to $-22 \mathrm{~m}$.), and the cave 7 site. B. Map of the excavation (GIBRAMAR Project) in the cave 7 area. C. Grain-size analysis of the sample VLA-047: bar-diagram (C, colloids. VFC, very fine clay. FC, fine clay. MC, medium clay. CC, coarse clay. VFS, very fine silt. FS, fine silt. MS, medium silt. CS, coarse silt. VFSa, very fine sand. FSa, fine sand. MSa, medium sand. CSa, coarse sand. VCSa, very coarse sand. G, gravel) and percentage, grouping grain size in the pie-diagram.

Fig. 5.- Arrecife de Vladi (V en la Fig. 1B). A. Perfil esquemático de la cresta rocosa con las elevaciones (de -19 m a -22 m s.n.m.) y localización de la cueva 7. B. Plano de la excavación (Proyecto GIBRAMAR) en el entorno de la cueva 7. C. Granulometría de la muestra VLA-047: Análisis detallado en el diagrama de barras (C, coloides. VFC, arcilla muy fina. FC, arcilla fina. MC, arcilla media. CC, arcilla gruesa. VFS, limo muy fino. FS, limo fino. MS, limo medio. CS, limo grueso. VFSa, arena muy fina. FSa, arena fina. MSa, arena media. CSa, arena gruesa. VCSa, arena muy gruesa. G, grava) y porcentajes, agrupando tamaños de grano en el diagrama circular.

et al., 2005). A very similar situation with cave-fillings has been described by Mörner and Dawson (2011) in the Maldives islands. In this paper, the authors introduce the concept of "submarine sandstorms" in association with tsunami events, and they showed that such "sandstorms" may reach considerable depths where they are even depositing significant sand wedges in the submarine caves. Thereby, some caves were found in the Maldives islands with sand fillings containing shallow-water corals and gastropods, which were subjected to ${ }^{14} \mathrm{C}$-dating. These caves are located between 20 and $38 \mathrm{~m}$ below the sea surface and allowed differentiating up to five events, some of which are correlative with historical tsunamis.

\section{Conclusions}

In three different sections of Gibraltar, corresponding to three different environments, evidences of the AD 1755 Lisbon tsunami were found.
1) A $36 \mathrm{~cm}$ thick sandy formation, which is arranged on another one that is peat and organic matter rich, was found in a boring performed in the isthmus that links the Rock to the mainland. This second unit corresponds to the filling of a lagoon (The Inundation lagoon) that existed until the mid-twentieth century and disappeared following the construction of the airport. Meanwhile, the sandy unit represents the deposit of a high-energy event that eroded the underlying organic-rich sediments and incorporated them within a large volume of sands transported from adjacent coastal areas and sandy Pliocene outcrops. This deposit was ascribed to the AD 1755 tsunami after the finding of a hand grenade fragment, which dates to the 1770-1780's.

2) In the area known as Rosia Bay, southwest of the Rock, an open-crevice was found in the coastal cliff, which is partly filled with sediments from several tsunamis. It was also possible to clarify and identify some of them with the dating of marine faunal debris associated 
with the deposit and arranged at different levels. This way, at about $5 \mathrm{~m}$ heigth, material transported there by the AD 1755 tsunami was found.

3) Finally, in the continental shelf, south of Gibraltar, submarine caves located at $22 \mathrm{~m}$ below the sea level were studied. These caves show a superficial filling, mostly sandy, that covers previous rocky blocks. Due to the properties of this sandy material and according to the dating of the fauna associated, it was interpreted as a subaqueuos tsunami deposit, which corresponds to the backwash of the AD 1755 event.

When compared to other Atlantic coastal sectors where wave heights could have exceeded $10 \mathrm{~m}$ (Cape St. Vincent), the evidences presented for this tsunami along the Gibraltar coast indicate that, at least in this area, the wave energy was superficially attenuated. Nevertheless, this energy left its most visible mark along the rocky coasts, where the onslaught of the wave reached above $5 \mathrm{~m}$. In the flattest area of the sector - the isthmus - the wave reached a maximum distance of $200 \mathrm{~m}$ and the sandy sediment dragged by the washover reached $100 \mathrm{~m}$ from the western coast line. Finally, according to the submarine evidence, the tsunami reached significant erosive power in the currents caused by the submarine backwash, which reached depths of $22 \mathrm{~m}$.

\section{Acknowledgements}

Research supported by the Spanish-FEDER Project CGL2010-15810/BTE, AHRC Research Grants (AH/ E009409/1), and COST-action TD0902 SPLASHCOS (Submerged Prehistoric Archeology and Landscapes of the Continental Shelf). We thank reviewers and guest-editors for helpful comments. It is a contribution to IGCPs 526 (Risks, resources, and record of the past on the continental shelf), 567 (Earthquake Archaeology and Palaeoseismology), and 588 (Preparing for coastal change).

\section{References}

Abe, K. (1979): Size of great earthquakes of 1837-1974 inferred from tsunami data, Journal of Geophysical Research 84, 1561-1568. doi: 10.1029/JB084iB04p01561.

Abrantes, F., Lebreiro, S., Gil, I., Rodrigues, T., BartelsJónsdóttir, H., Oliveira, P., Kissel, C., Grimalt, J. O. (2005): Shallow marine sediment cores record climate variability and earthquake activity off Lisbon (Portugal) for the last 2000 years. Quaternary Science Reviews 24, 2477-2494. doi: 10.1016/j.quascirev.2004.04.009.

Abrantes, F., Alt-Epping, U., Lebreiro, S., Voelker, A., Schneider, R. (2008): Sedimentological record of tsunamis on shallow-shelf areas: The case of the $1969 \mathrm{AD}$ and $1755 \mathrm{AD}$ tsunamis on the Portuguese Shelf off Lisbon. Marine Geology 249, 283-293. doi:10.1016/j.margeo.2007.12.004.

Alonso, C., Gracia, F. J., Anfuso, G., Del Río, L., Benavente, J., Martínez, J. A. (2004): Registro morfosedimentario de eventos históricos de alta energía en el litoral atlántico del Estrecho de Gibraltar (Trafalgar-Tarifa). In: Benito, G., Díez Herrero, A. (eds.): Contribuciones recientes sobre Geomorfología 263-271, C. S. I. C., Madrid.

Andrade, C. (1992): Tsunami generated forms in the Algarve barrier islands (South Portugal). Science of Tsunami Hazards 10, 21-34.

Andrade, C., Hindson, R., Freitas, C., Dawson, A. (1994): Sedimentary evidence of tsunami flooding in Algarve coastal lowlands. Proceedings of the Symposium Littoral '94, Lisbon, vol. II, 26-29.

Andrade, C., Andrade, A. M., Kortekaas, S., Dawson, A. (1997): Sedimentological traces of tsunamigenic overwash of the Martinhal lowland (Western Algarve, Portugal). Proceedings of the Symposium Littoral '97, Faro, 11-17.

Andrade, C., Munhá, J. M., Paulino, J. (1998): Geochemical signature of extreme marine flooding in the Boca do Rio lowland (Algarve, Portugal). Com. V Congresso Nacional de Geología, Lisboa, IGN, SGP, 84(1), C-51/C-54.

Andrade, C., Borges, P., Freitas, M. C. (2006): Historical tsuna$\mathrm{mi}$ in the Azores archipielago (Portugal). Journal of Volcanology and Geothermal Research 156, 172-185. doi:10.1016/j. jvolgeores.2006.03.014.

Atwater, B. F., ten Brink, U. S., Buckley, M., Halley, R. S., Jaffe, B. E., López-Venegas, A. M., Reinhardt, E. G., Tuttle, M. P., Watt, S., Wei, Y. (2010): Geomorphic and stratigraphic evidence for an unusual tsunami or storm a few centuries ago at Anegada, British Virgin Islands. Natural Hazards, doi:10.1007/s11069-010-9622-6.

Baptista, M. A., Heitor, S., Mendes Victor, L. (1998a): The 1755 Lisbon tsunami; Evaluation of the tsunami parameters, Journal of Geodynamics 25, 143-157. doi:10.1016/S02643707(97)00019-7.

Baptista, M. A., Miranda, P. M., Miranda, J. M., Mendes Victor, L. (1998b): Constrains on the source of the 1755 Lisbon tsunami inferred from numerical modelling of historical data. Journal of Geodynamics 25, 159-174. doi:10.1016/ S0264-3707(97)00020-3.

Baptista, M. A., Miranda, J. M., Chierici, F., Zitellini, N. (2003): New study of the 1755 earthquake source based on multi-channel seismic survey data and tsunami modeling, Natural Hazards and Earth System Sciences 3, 333-340.

Baptista, M. A., Miranda, J. M. (2009): Revision of the Portuguese catalog of tsunamis, Natural Hazards and Earth System Sciences 9, 25-42.

Barkan R., ten Brink U. S., Lin J. (2009): Far field tsunami simulations of the 1755 Lisbon earthquake: Implications for tsunami hazard to the U.S. East Coast and the Caribbean. Marine Geology 264, 109-122. doi:10.1016/j.margeo.2008.10.010.

Bewick, B. (1757): An account of the Earthquake at Cádiz, 
November 1, 1755, in a Letter from Benjamin Bewick, Merchant there, to Mr. Joseph Paice, Merchant in London, Lett. XIV, for the Year 1756, Philosophical Transactions, Vol. XLIX, Part II, London.

Blanc, P. L. (2008): The tsunami in Cádiz on 1 November 1755: a critical analysis of reports by Antonio de Ulloa and by Louis Godin, Comptes Rendus Geoscience 340, 251-261. doi:10.1016/j.crte.2007.12.001.

Blanc, P. L. (2009): Earthquakes and tsunami in November 1755 in Morocco: a different reading of contemporaneous documentary sources. Natural Hazards of Earth System Sciences 9, 725-738.

Borlase, W. (1755): Letter to the Rev. Charles Lytleton, L. L. Dean of Exeter, Lett. XV, printed for L. Davis and C. Reymers, Printers to the Royal Society, against Gray's Inn Gate, in Holbourn, for the Year 1756, Philosophical Transactions Vol. XLIX, Part II, London 1757.

Chambers, C. (1757): Another account of the same earthquake at Madeira in a letter from Charles Chambers to his father, in London, dated at Madeira, Novem. I, 1755, Communicated by Lewis Crusius, D. D. F. R. S., Lett. XVIII, for the Year 1756, Philosophical Transactions Vol. XLIX, Part II, London.

Clague, J. J., Bobrowsky, P. T., Hutchinson, I. (2000): A review of geological records of large tsunamis at Vancouver Island, British Columbia, and implications for hazard. Quaternary Science Reviews 19, 849- 863. doi:10.1016/S02773791(99)00101-8.

Cunha, P. P., Buylaert, J.-P., Murray, A. S., Andrade, C., Freitas, M. C., Fatela, F., Munhá, J. M., Martins, A. A., Sugisaki, S. (2010): Optical dating of clastic deposits generated by an extreme marine coastal flood: the 1755 tsunami deposits in the Algarve (Portugal). Quaternary Geochronology 5, 329-335.

Dabrio, C. J., Goy, J. L., Zazo, C. (1998): The record of the tsunami produced by the 1755 Lisbon Earthquake in Valdelagrana spit (Gulf of Cádiz, Southern Spain). Geogaceta 23, 31-34.

Dawson, A. G., Hindson, R., Andrade, C., Freitas, C., Parish, R., Bateman, M. (1995): Tsunami sedimentation associated with the Lisbon earth-quake of 1 November AD 1755: Boca do Rio, Algarve, Portugal. The Holocene 5, 209-215. doi:10.1177/095968369500500208.

Dawson, A.G., Stewart, I. (2007): Tsunami deposits in the geological record. Sedimentary Geology 200, 166-183. doi:10.1016/j.sedgeo.2007.01.002.

Drinkwater, J. (1785): History of the Late Siege of Gibraltar. Spilsbury, London.

Fa, D., Finlayson, C. (2006): The Fortifications of Gibraltar 1068-1945. Osprey Publishing, Oxford.

Flemming, N. C. (1972): Relative chronology of submerged Pleistocene marine erosion features in the western Mediterranean. Journal of Geology 80, 633-662.

Fonseca, J. F. B. D. (2005): The source of the Lisbon earthquake. Science 308, 50-51. doi:_10.1126/science.308.5718.49a.

Font, E., Nascimiento, C., Omira, R., Baptista, M. A., Silva, P. F. (2010): Identification of tsunami-induced deposits using numerical modeling and rock magnetism techniques: A study case of the 1755 Lisbon tsunami in Algarve, Portugal. Physics of the Earth and Planetary Interiors 182, 187-198. doi:10.1016/j.pepi.2010.08.007.

Fowke, Th. (1756): An account of the earthquake in Barbary, inclosed in a letter from General Fowke, Governor of Gibraltar, to the Right Honourable Henry Fox, Philosophical Transactions, Vol. XLIX, part I, for the year 1756, 428-432.

Garcia-Orellana, J., Gràcia, E., Vizcaino, A., Masqué, P., Olid, C., Martínez-Ruiz, F., Piñero, E., Sanchez-Cabeza, J. A., Dañobeitia, J. J. (2006): Identifying instrumental and historical earthquake records in the SW Iberian Margin using $210 \mathrm{~Pb}$ turbidite chronology. Geophysical Research Letters 33, L24601. doi:10.1029/2006GL028417.

Godin, L. (1755): Sur le Tremblement de Terre qui s'est fait sentir `a Cadix le 1er novembre 1755 (lu par Bouguer), P.-V. Acad. Roy. Sci. Paris 74, 772-781, 3 and 6 d'ecembre 1755.

Goff, J. R., McFadgen, B. G. (2002): Seismic driving of nationwide changes in geomorphology and prehistoric settlement - a $15^{\text {th }}$ century New Zealand example. Quaternary Science Reviews 22, 2229- 2236. doi:10.1016/ S0277-3791(02)00033-1.

Goto, K., Takashashi, J., Oie, T., Imamura, F. (2011): Remarkable bathymetric change in the nearshore zone by the 2004 Indian Ocean tsunami: Kirinda Harbor, Sri Lanka. Geomorphology 127, 107-116. doi:10.1016/j.geomorph.2010.12.011.

Gràcia E., Vizcaino, A., Escutia, C., Asioli, A., Rodés, A., Pallàs, R., Garcia-Orellana, J., Lebreiro, S., Goldfinger, C. (2010): Holocene earthquake record offshore Portugal (SW Iberia): testing turbidite paleoseismology in a slow-convergence margin. Quaternary Science Reviews 29, 1156-1172. doi:10.1016/j.quascirev.2010.01.010.

Gracia, F. J., Alonso, C., Anfuso, G., Benavente, J., Del Río, L., Domínguez, L., Martínez, J. A. (2005): Historical evolution and erosion problems in the Cádiz coasts. In: Gracia, F. J. (Coord.): Field trip guide A-4. Geomorphology of the South-Atlantic Spanish Coast, 40-58. $6^{\text {th }}$ International Conference on Geomorphology, I. A. G., Zaragoza.

Gracia, F. J., Alonso, C., Benavente, J., Anfuso, G., Del Río, L. (2006): The different coastal records of the 1755 tsunami waves along the South Atlantic Spanish coast. Zeitschrift für Geomorphologie Suppl. 146, 195-220.

Gutscher, M. A. (2004): What caused the Great Lisbon earthquake? Science 305, 1247-1248. doi:10.1126/science.1101351.

Gutscher M. A., Baptista M. A., Miranda J. M. (2006): The Gibraltar Arc seismogenic zone (part 2): Constraints on a shallow east dipping fault plane source for the 1755 Lisbon earthquake provided by tsunami modeling and seismic intensity. Tectonophysics 426, 153-166. doi:10.1016/j.tecto.2006.02.025.

Hindson, R. A., Andrade, C. (1999): Sedimentation and hydrodynamic processes associated with the tsunami generated by the 1755 Lisbon earthquake. Quaternary International 56, 27-38. doi:10.1016/S1040-6182(98)00014-7. 
Hindson, R. A., Andrade, C., Dawson, A. G. (1996): Sedimentary processes associated with the tsunami generated by the 1755 Lisbon earthquake on the Algarve coast, Portugal. Physics and Chemistry of the Earth 21, 57-63. doi:10.1016/ S0079-1946(97)00010-4.

Hughen, K. A., Baillie, M. G., Bard, E., Beck, J. W., Bertrand, C. J. H., Blackwell, P. G., Buck, C. E., Burr, G. S., Cutler, K. B., Damon, P. E., Edwards, R. L., Fairbanks, R. G., Friedrich, M., Guilderson, T. P., Kromer, B., McCormac, G., Manning, S., Bronk Ramsey, C., Reimer, P. J., Reimer, R. W., Remmele, S., Southon, J. R., Stuiver, M., Talamo, S., Taylor, F. W., Van der Plicht, J., Weyhenmeyer, C. E. (2004): Marine04: marine radiocarbon age calibration, 0-26 cal kyr BP. Radiocarbon 46, 1059-1086.

IGN (2005): Terremotos y Tsunamis en España, Instituto Geográfico Nacional, CD version.

James, T. (1771): The History of the Herculean Straits, now called The Straits of Gibraltar: including those ports of Spain and Barbary that lies contiguous thereto, London, vol.2, $414 \mathrm{pp}$.

Jiménez-Munt, I., Negredo, A. M. (2003): Neotectonic modelling of the western part of the Africa-Eurasia plate boundary: from the Mid-Atlantic ridge to Algeria. Earth and Planetary Science Letters 205, 257-271.

Johnston, A. C. (1996): Seismic moment assessment of earthquakes in stable continental regions - III, New Madrid 1811-1812, Charleston 1886 and Lisbon, 1755. Geophysical Journal International 126, 314-344. doi:10.1111/j.1365246X.1996.tb05294.x.

Kaabouben, F., Baptista, M. A., Iben Brahim, A., El Mouraouah, A., Toto, A. (2009): On the moroccan tsunami catalogue. Natural Hazards of Earth System Sciences 9, 12271236.

Kortekaas, S., Dawson, A. (2007). Distinguishing tsunami and storm deposits: an example from Martinhal, SW Portugal. Sedimentary Geology 200, 208-221. doi:10.1016/j.sedgeo.2007.01.004.

Koster, B., Vonberg, D., Reicherter, K. (2009): Tsunamigenic deposits along the southern Gulf of Cádiz (Southwestern Spain) caused by tsunami in 1755? In: Pérez-López, R., Grützner, C., Lario, J., Reicherter, K., Silva, P.G. (eds.). Archaeoseismology and Palaeoseismology in the Alpine-Himalayan Collisional Zone. $1^{\text {st }}$ INQUA-IGCP-567 International Workshop on Earthquake Archaeology and Palaeoseismology. Abstracts Volume. Escuela Técnica Superior de Ingenieros Industriales. Universidad Politécnica de Madrid, 73-75.

Lander, J. F., Whiteside, L. S., Lockridge, P. A. (2002): Brief history of Tsunamis in the Caribbean Sea. Science of Tsunami Hazards 20, 2, 57-94.

Lario, J., Zazo, C., Plater, A. J., Goy, J. L., Dabrio, C. J., Borja, F., Sierro, F. J., Luque, L. (2001): Particle size and magnetic properties of Holocene estuarine deposits from the Doñana National Park (SW Iberia): evidence of gradual and abrupt coastal sedimentation. Zeitschrift für Geomorphologie 45, $33-54$.

Lebreiro, S. M., McCave, I. N., Weaver, P. P. E. (1997):
Late Quaternary turbidite emplacement on the Horseshoe Abyssal Plain (Iberian Margin). Journal of Sedimentary Research 67, 856-870. doi:10.1306/D4268658-2B26-11D7$8648000102 \mathrm{C} 1865 \mathrm{D}$.

Levret, A. (1991): The effects of the November 1, 1755 'Lisbon' earthquake in Morocco, Tectonophysics 193, 83-94. doi:10.1016/0040-1951(91)90190-4.

Luque, L., Lario, J., Zazo, C., Goy, J. L., Dabrio, C. J., Silva, P. G. (2001): Tsunami deposits as paleoseismic indicators: examples from the Spanish coast. Acta Geologica Hispanica 36, 197-211.

Luque, L., Zazo, C., Lario, J., Goy, J. L., Civis, J., González, F. M., Silva, P. G., Dabrio, C. J., Silva, P. G. (2004): El efecto del tsunami del año 1755 en el litoral de Conil de la Frontera (Cádiz). In: Baquedano, E., Rubio, S. (eds). Miscelánea en homenaje a Emiliano Aguirre, vol. 1, Geología 73-82, Zona arqueológica, 4, Alcalá de Henares.

Machado, F. (1966): Contribução para o estudo do terremoto de 1 de Novembro de 1755. Revista da Faculdade de Ciências de Lisboa Ser. C 14, 19-31.

Mhammdi, N., Medina, F., Kelletat, D., Ahmamou, M., Aloussi, L. (2008): Large boulders along the Rabat coast (Morocco); possible emplacement by the November, $1^{\text {st }}, 1755 \mathrm{AD}$ tsunami. Science of Tsunami Hazards 27, 17-30.

Martínez Solares, J. A., López Arroyo, A., Mezcua, J. (1979): Isoseismal map of the 1755 Lisbon earthquake obtained from Spanish data. Tectonophysics 53, 301-313. doi:10.1016/0040-1951(79)90075-1.

Mendonça, J. M. (1758): Historia Universal dos Terramotos que tem havido no mundo de que há noticia desde a sua criaçao até ao seculo presente. Biblioteca Nacional de Lisboa, Portugal, $272 \mathrm{pp}$.

Morales, J. A., Borrego, J., San Miguel, E. G., López-González, N., Carro, B. (2008): Sedimentary record of recent tsunamis in the Huelva Estuary (southwestern Spain), Quaternary Science Reviews 27, 734-746. doi:10.1016/j.quascirev.2007.12.002.

Moreira, V. S. (1989): in Gregersen S., P. W. Basham, (eds). Earthquakes at North-Atlantic Passive Margins: Neotectonics and Postglacial Rebound, NATO ASI series. Kluwer Academic Publisher, London.

Mörner, N.-A., Dawson, S. (2011): Traces of tsunami events in off- and on-shore environments. Case studies in the Maldives, Scotland and Sweden. In: Mörner, N.-A. (ed). The tsunami threat - research and Technology 371-388, InTechn Open Access Publisher.

Oliveira, M. A., Andrade, C., Freitas, M. C., Costa, P. J. (2009): Modeling volume transfer between beach-foredune and the backshore by the 1755 Lisbon tsunami at Boca do Rio lowland, Algarve (Portugal). Journal of Coastal Research Special issue $56,1547-1551$.

O’Loughlin, K. F., Lander, J. F. (2003): Caribbean tsunamis; a 500 year history from 1498-1998. Kluwer Academic, Dordrecht.

Pozo, M., Ruiz, F., Carretero, M. I., Rodríguez-Vidal, J., Cáceres, L. M., Abad, M., González- Regalado, M. L., 
(2010): Mineralogical assemblages, geochemistry and fossil associations of Pleistocene-Holocene complex siliciclastic deposits from the Southwestern Doñana National Park (SW Spain): a palaeoenvironmental approach. Sedimentary Geology 225, 1-18. doi:10.1016/j.sedgeo.2010.01.002.

Radtke, U., Schellmann, G., Scheffers, A., Kelletat, D., Kromer, B., Uwe, H. (2003): Electron spin resonance and radiocarbon dating of coral deposited by Holocene tsunami events on Curacao, Bonaire and Aruba (Netherlands Antilles). Quaternary Science Reviews 22, 1309-1315. doi:10.1016/S02773791(03)00036-2.

Reid, H. F. (1914): The Lisbon earthquake of November 1, 1755. Bulletin of the Seismological Society of America 4, 53-80.

Reimer, P. J., Baillie, M. G. L., Bard, E., Bayliss, A., Beck, J. W., Blackwell, P. G., Bronk Ramsey, C., Buck, C. E., Burr, G. S., Edwards, R. L., Friedrich, M., Grootes, P. M., Guilderson, T. P., Hajdas, I., Heaton, T. J., Hogg, A. G., Hughen, K. A., Kaiser, K. F., Kromer, B., McCormac, F. G., Manning, S. W., Reimer, R. W., Richards, D. A., Southon, J. R., Talamo, S., Turney, C. S. M., van der Plicht. J., Weyhenmeyer, C. E. (2009): IntCal09 and Marine09 radiocarbon age calibration curves, $0-50,000$ years cal BP. Radiocarbon 51, 1111-1150.

Rodríguez-Vidal, J., Ruiz, F., Cáceres, L. M. (2009): Comment on "Formation of chenier plain of the Doñana marshland (SW Spain): Observations and geomorphic model" by A. Rodríguez-Ramírez and C.M. Yáñez-Camacho [Marine Geology 254 (2008) 187-196]. Marine Geology 263, 120-122. doi:10.1016/j.margeo.2009.02.012.

Rollo, D. (1989). Guns on the Rock: The British Artillery Defences of Gibraltar, 1704 to 1989. Based on the 1958 typescript by Major C.B.A. Hire in the Gibraltar Museum. Copy in the Gibraltar Museum, 1990.

Ruiz, F., Rodríguez-Ramírez, A., Cáceres, L. M., Rodríguez Vidal, J., Carretero, M. I., Abad, M., Olías, M., Pozo, M., (2005): Evidence of high-energy events in the geological record: Mid-Holocene evolution of the southwestern Doñana National park (SW Spain). Palaeogeography, Palaeoclimatology, Palaeoecology 229, 212-229. doi:10.1016/j.palaeo.2005.06.023.

Ruiz, F., Abad, M., Rodríguez-Vidal, J., Cáceres, L. M., González-Regalado, M. L., Carretero, M. I., Pozo, M., Gómez Toscano, F., (2008): The geological record of the oldest historical tsunamis in southwestern Spain. Rivista Italiana di Paleontologia e Stratigrafia 114, 147-156.

Shepherd, J. B. (2001): Tsunami Hazard in the Caribbean. Workshop on volcanic and seismic hazards in the eastern Caribbean, 28 May-1 June 2001.

Smith, D. E., Shi, S., Cullingford, R. A., Dawson, A. G., Dawson, S., Firth, C. R., Foster, I. D. L., Fretwell, P. T., Haggart, B. A., Holloway, L. K., Long, L. (2004): The Holocene Storegga Slide tsunami in the United Kingdom. Quaternary
Science Reviews 23, 2291-2321. doi:10.1016/j.quascirev.2004.04.001.

Soares, A. M. M., Dias, J. M. A. (2006): Coastal upwelling and radiocarbon-evidence for temporal fluctuations in ocean reservoir effect off Portugal during the Holocene. Radiocarbon 48, 45-60.

Soares, A. M. M., Martins, J. M. M. (2010): Radiocarbon dating of marine samples from Gulf of Cadiz: The reservoir effect. Quaternary International 221, 9-12. doi:10.1016/j. quaint.2009.10.012.

Solares, J. M. M., Arroyo, A. L. (2004): The great historical 1755 earthquake. Effects and damage in Spain. Journal of Seismo$\operatorname{logy}$ 8, 275 pp. doi:10.1023/B:JOSE.0000021365.94606.03.

Srinivasalu, S., Jonathan, M. P., Thangadurai, N., Ram-Mohan, V. (2010): A study on pre- and post-tsunami shallow deposits off SE coast of India from the 2004 Indian Ocean tsunami: a geochemical approach. Natural Hazards 52, 391-401. doi:10.1007/s11069-009-9385-0.

Terrinha, P., Pinheiro, L. M., Henriet, J. P., Matias, L., Ivanov, M. K., Monteiro, J. H., Akhmetzhanov, A., Volkonskaya, A., Cunha, T., Shaskin, P., Rovere, M. (2003): Tsunamigenic-seismogenic structures, neotectonics, sedimentary processes and slope instability on the southwest Portuguese Margin. Marine Geology 195, 55-73. doi:10.1016/S00253227(02)00682-5.

Thomson, J., Weaver, P. P. E., (1994): An AMS radiocarbon method to determine the emplacement time of recent deep-sea turbidites. Sedimentary Geology 89, 1-7. doi:10.1016/00370738(94)90079-5.

Vizcaino, A., Gràcia, E., Pallás, R., García-Orellana, J., Escutia, C., Casas, D., Willmott, V., Diez, S., Asioli, A., Dañobeitia, J. J. (2006): Sedimentology, physical properties and ages of mass-transport deposits associated to the Mârques de Pombal Fault, Southwest Portuguese Margin. Norwegian Journal of Geology 86, 177-186.

Whelan, F., Kelletat, D. (2005): Boulder deposits on the southern Spanish Atlantic coast: possible evidence for the 1755 AD Lisbon tsunami? Science of Tsunami Hazards 23 (3), 25-38.

White, J. (1913): Fauna Calpensis (A Natural History of Gibraltar and Southern Spain). Edited by W.H. Mullens, The Selborne Society, London, $24 \mathrm{pp}$.

Zitellini, N., Chierici, F., Sartori, R., Torelli, L. (1999): The tectonic source of the 1755 Lisbon Earthquake. Annali di Geofisica 42, 1, 49-55.

Zitellini, N., Mendes Victor, L. A., Cordoba, J. D. (2001): Source of 1755 Lisbon Earthquake and tsunami Investigated. EOS 82 (26), 285. doi:10.1029/EO082i026p00285-01.

Zitellini, N., Rovere, M., Terrinha, P., Chierici, F., Matias, L., and BIGSETS TEAMS (2004): Neogene through Quaternary tectonic reactivation of SW Iberian Passive Margin. Pure and Applied Geophysics 161, 565-587. doi:10.1007/ s00024-003-2463-4. 